\title{
Wide-angle refraction experiments in the Daito Ridges region at the northwestern end of the Philippine Sea plate
}

\author{
Azusa Nishizawa*, Kentaro Kaneda, Yasutaka Katagiri and Mitsuhiro Oikawa
}

\begin{abstract}
Three large bathymetric highs (from north to south: the Amami Plateau, the Daito Ridge, and the Oki-Daito Ridge) originating from paleo-island arcs characterize the northwestern end of the Philippine Sea plate. We obtained 10 seismic refraction and multi-channel seismic reflection profiles across and along these bathymetric highs and obtained $P$ wave velocity $(V p)$ models of the crust and the uppermost mantle. Although there are large variations in the crustal structure throughout this region, these bathymetric highs usually have a middle crust with Vp of 6.3 to $6.8 \mathrm{~km} / \mathrm{s}$, a lower crust with Vp of 6.8 to $7.2 \mathrm{~km} / \mathrm{s}$, a Pn velocity of 7.6 to $7.8 \mathrm{~km} / \mathrm{s}$, and a total crustal thickness of 15 to $25 \mathrm{~km}$. These features are similar to those of the Izu-Ogasawara (Bonin)-Mariana island arc and the Kyushu-Palau Ridge, which are immature paleo-island arcs. However, the crust at the southwestern part of the Oki-Daito Ridge contains a relatively thin middle crust and a smaller total crustal thickness compared with other ridges in this region. In addition, we identified a deep reflector beneath the ridge, with these properties indicating a different origin, such as intraplate volcanism.
\end{abstract}

Keywords: Daito Ridges; $P$ wave velocity structure; Paleo-island arc

\section{Background}

The Philippine Sea plate is composed of three inactive marginal basins, the Shikoku Basin, the Parece Vela Basin, and the West Philippine Basin, as well as many bathymetric highs (Figure 1). The evolutionary histories of these basins have been mostly elucidated based on geophysical and geological data (e.g., Kobayashi et al. 1995; Okino et al. 1999; Deschamps and Lallemand 2002). The northwestern end of the Philippine Sea plate is characterized by several old bathymetric highs, known as the Daito Ridges. From north to south, these comprise the Amami Plateau, the Daito Ridge, and the Oki-Daito Ridge, with models for their evolution having been presented in various studies (e.g., Tokuyama et al. 1986; Tokuyama 2007; Ishizuka et al. 2013). The latitude at which these bathymetric highs formed was investigated by Ueda (2004) using topographic and magnetic anomaly data. Paleolatitudes of $15.1^{\circ} \pm 4.6^{\circ} \mathrm{N}$ for the Amami Plateau, $20.1^{\circ} \pm 8.2^{\circ} \mathrm{N}$ for the Daito Ridge, and $4.4^{\circ} \pm 11^{\circ} \mathrm{S}$ for the Oki-Daito Ridge were obtained,

\footnotetext{
* Correspondence: azusa@mail1.accsnet.ne.jp

Hydrographic and Oceanographic Department, Japan Coast Guard, 2-5-18 Aomi, Koto-ku, Tokyo 135-0064, Japan
}

showing that these bathymetric highs initially formed south of their present positions and have since migrated northwards.

The topographic highs of the Amami Plateau consist of three east-west-oriented ridges that extend for approximately $300 \mathrm{~km}$, with the middle ridge being both the largest and the shallowest in depth (less than 2,000 m). The northwestern end of the plateau is currently subducting beneath the Ryukyu (Nansei-Shoto) Trench (Nishizawa et al. 2009). Igneous rocks obtained from the plateau suggest that its pedestal is Cretaceous in age, and the ridge portion situated on the pedestal formed in the Middle Eocene (Tokuyama et al. 1986; Ishizuka and Yuasa 2007). Hickey-Vargas (2005) described basalt and tonalite from the Amami Plateau that have geochemical characteristics of intra-oceanic island arc rocks and which formed at 70 to $118 \mathrm{Ma}$ during the Cretaceous. Based on these data, Tokuyama (2007) concluded that the Amami Plateau was an active island arc before the Eocene.

The Daito Ridge is situated south of the Amami Plateau; its western end approaches the Ryukyu Trench, and its eastern end connects to the Kyushu-Palau Ridge. The 


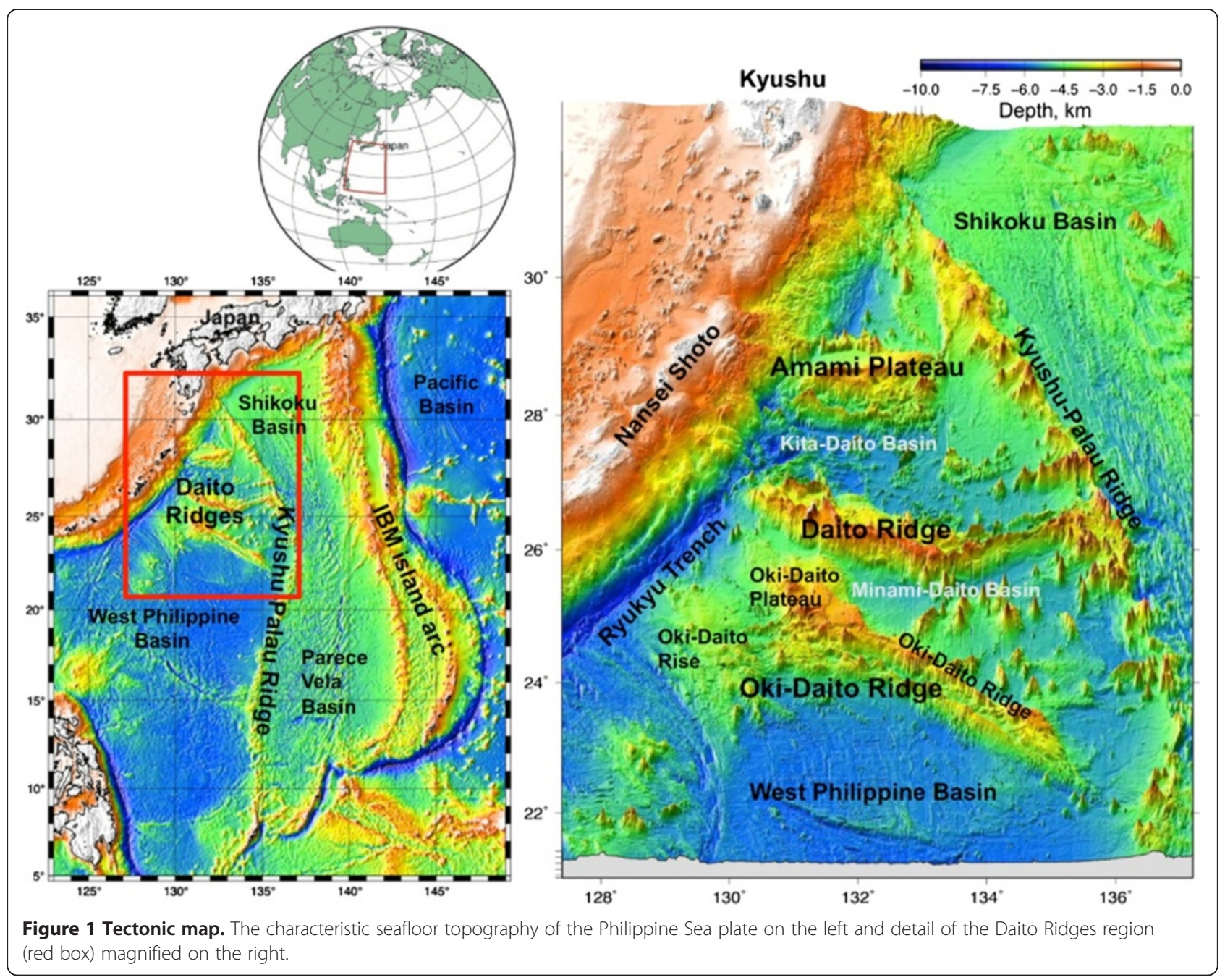

Daito Ridge is 500-km long, east-west trending and shows an arched topography facing south. The ridge is divided into a shallow, wide, and flat bottom in the west and a narrow ridge in the east. Samples of basalt obtained from DSDP Site 445 at the center of the ridge (Figure 2a) were determined by Tokuyama et al. (1986) to be middle Eocene in age and to have originated in an island arc setting. Furthermore, Ishizuka and Yuasa (2007) estimated the age of the aphyric basalt recovered from the western part of the Daito Ridge to be $116.9 \mathrm{Ma}$, which mostly agrees with the reported ages of igneous rocks elsewhere in the Amami Plateau.

Further south, the Oki-Daito Ridge, in the broad sense, has a total length of approximately $700 \mathrm{~km}$ and is topographically divided into three parts: the Oki-Daito Rise in the southwest, the Oki-Daito Plateau in the northwest, and the Oki-Daito Ridge in the strict sense hereafter referred to simply as the Oki-Daito Ridge in the east (Figure 1). The Oki-Daito Plateau connects with the Daito Ridge at its northwestern end. The Oki-Daito Ridge is characterized by two rows of linear bathymetric highs that have a V-shaped topographic depression between them. Volcanic edifices on the Oki-Daito Ridge and the MinamiDaito Basin to the north have geochemical characteristics similar to ocean island basalt (OIB) and have an estimated age of 44 to $48 \mathrm{Ma}$ (Ishizuka et al. 2013). By contrast, alkali basalt dredged at the southeastern bathymetric high on the Oki-Daito Ridge has an age of $65 \mathrm{Ma}$ and formed through undetermined volcanic activity (Okino and Kato 1992). As a result, these data indicate that volcanic activity has occurred on at least two separate occasions in this region.

Kasuga et al. (1986) analyzed gravitational and geomagnetic data from the region around the Daito Ridge and the northern Oki-Daito Ridge, and reported that free air and Bouguer gravity anomalies indicate that the crust below the ridges is thick. Furthermore, magnetic anomalies suggest that these ridges have a magnetic basement with properties characteristic of intermediate and acidic rock types, combined with several intrusive rocks that have 


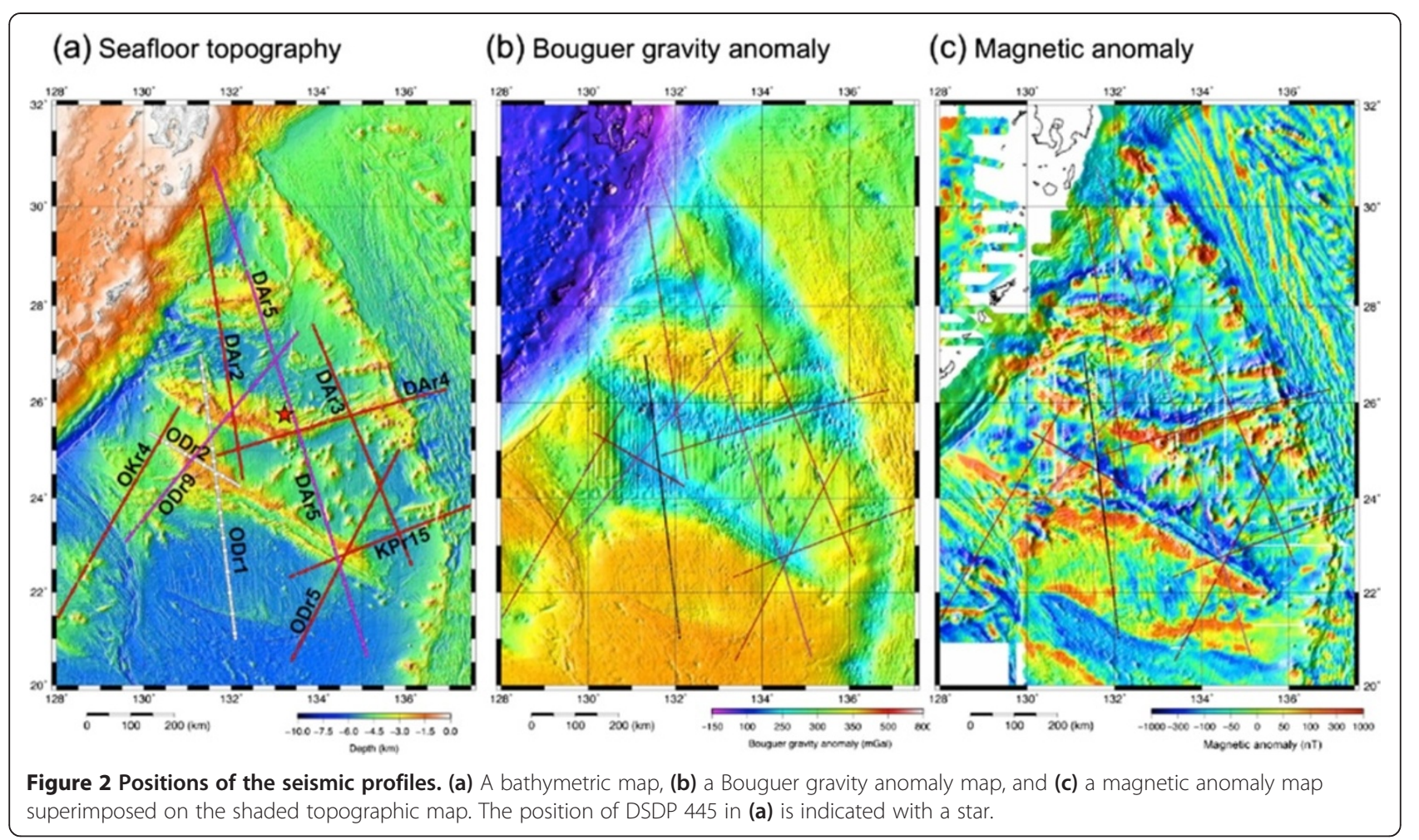

intermediate and basic rock properties (Kasuga et al. 1986). They concluded that the two ridges are remnants of island arcs, on the basis of previous results from rock samples and other geological features.

Ishihara and Koda (2007) gravimetrically estimated the crustal thickness of the Philippine Sea plate using a simple four-layer model, which comprised seawater, sediments, crust, and lithospheric mantle, with respective densities of $1,030,2,300,2,800$, and $3,300 \mathrm{~kg} / \mathrm{m}^{3}$. Their results show that the Amami Plateau, the Daito Ridge, and the Oki-Daito Ridge (in the broad sense) have crusts of 15- to $20-\mathrm{km}$ thickness. However, they could not constrain its overall constitution (i.e., the relative proportions of the upper, middle, and lower crusts). Furthermore, there is insufficient information about densities and sediment distribution to obtain a more thorough image of the crustal structure in this region.

Various seismic refraction experiments have been conducted in this region in an attempt to reveal more of its crustal structure. Murauchi et al. (1968) revealed that the Oki-Daito Ridge has a continental-type upper crust that is up to $5 \mathrm{~km}$ thick and has a $P$ wave velocity $(\mathrm{Vp})$ of $6 \mathrm{~km} / \mathrm{s}$. Exploration conducted by Nishizawa et al. (1983) using a small number of ocean bottom seismographs (OBSs) produced similar crustal models for beneath the Amami Plateau, which indicate an upper crust up to $4 \mathrm{~km}$ thick with $\mathrm{Vp}$ of 5.4 to $5.6 \mathrm{~km} / \mathrm{s}$. However, they did not obtain the precise depth of the Moho due to a lack of seismic energy and insufficient travel time data. There was also little available information to image the entire paleo-island arc crust region of the Daito Ridges.

Recently, Calvert (2011) reviewed island arc seismic velocity models and discussed two examples as evolutionary end members: the Aleutian arc, initiated in the Eocene and not significantly affected by extension and rifting, and the Izu-Ogasawara (Bonin)-Mariana (IBM) arc-backarc system, also initiated in the Eocene but variably affected by localized extension and two episodes of arc rifting and backarc spreading. Calvert (2011) divided both arc crusts into three parts based on their $\mathrm{Vp}$ and crustal thickness proportions and showed that their middle and lower crusts have higher seismic velocities than those of typical continental crust. Moreover, the Aleutian middle crust has $\mathrm{Vp}$ of 6.5 to $7.3 \mathrm{~km} / \mathrm{s}$, which is significantly higher than that of the IBM middle crust ( 6.0 to $6.8 \mathrm{~km} / \mathrm{s}$ ). Thus, comparing the arc crustal structure of the Daito Ridges with these arc models will provide important insight into their evolution.

From 2004 to 2006, we carried out extensive wideangle seismic and multi-channel seismic (MCS) explorations in the Daito Ridges region as part of the Japanese Continental Shelf Survey Project. This paper presents the first seismic images of the deeper structures beneath the bathymetric highs in this region and aims to contribute to future research into the early history of the Philippine Sea plate. 


\section{Methods}

The locations of our seismic profiles in relation to known bathymetric, Bouguer gravity anomaly, and magnetic anomaly data are shown in Figure 2. In this seismic experiment, we shot a tuned array of air guns with a volume of $8,040 \mathrm{in}^{3}$ (132 L) at intervals of $200 \mathrm{~m} \mathrm{(90} \mathrm{s)}$ for the wide-angle seismic profiles and at intervals of $50 \mathrm{~m}$ for the MCS profiles (480 channels, 60-folds). OBSs were deployed at an average interval of $5 \mathrm{~km}$, except for ODr1, where the interval was $3 \mathrm{~km}$.

We used pop-up type OBSs equipped with a threecomponent $4.5-\mathrm{Hz}$ geophone and a hydrophone. Sensor outputs were continuously recorded on a hard disc at a sampling rate of $200 \mathrm{~Hz}$ with a resolution of 24 bits. Each OBS has an acoustic release unit for retrieval. The OBS locations were determined using acoustic waves from a ship with GPS navigation and direct water waves from an air gun array to the OBS.

OBS record sections were produced by $4-$ to $16-\mathrm{Hz}$ bandpass filtering, predictive deconvolution (first zero crossing, operator length of $660 \mathrm{~ms}$ ), and a local slant stack to enhance the signal-to-noise ratio. We read out the arrival times of the refraction and reflection signals from these record sections. Using these data, we produced $\mathrm{Vp}$ models by a combination of tomographic inversion and two-dimensional forward modeling. An initial velocity model was produced with the upper sedimentary layer constrained by the MCS data. First arrival data were inverted for a two-dimensional velocity model using the tomo2d tomographic inversion code of Korenaga et al. (2000). We constructed the model from shallower to deeper crust by increasing the offset limits of the input travel time data. In the velocity models derived for all profiles, the horizontal grid spacing is $0.5 \mathrm{~km}$, and the vertical grid spacing gradually increases with depth according to the relation $0.05+(0.01 \times \text { depth }(\mathrm{km}))^{1 / 2} \mathrm{~km}$.

Tomographic inversion misfits were less than $50 \mathrm{~ms}$ for almost all velocity models, and the resolution and reliability of our models were examined using checkerboard tests. We built a reference model by adding sinusoidal anomalies with a horizontal dimension of $10 \mathrm{~km}$, a vertical dimension of $2.5 \mathrm{~km}$, and a velocity perturbation of $\pm 5 \%$ to the upper crust of our preferred final model. The vertical cells in the middle and lower crusts were 5 and $10 \mathrm{~km}$, respectively, in the vertical direction and $5 \mathrm{~km}$ in the horizontal direction. We used ray coverage in addition to checkerboard test results to represent model reliability. Better recovery of the checkerboard pattern and higher ray density indicate higher resolution.

To utilize reflection arrivals and low-amplitude refraction signals at distant offsets, we carried out forward modeling using a two-dimensional ray-tracing algorithm (Fujie et al. 2000; Kubota et al. 2009). We used the tomographic model as an initial ray-tracing model and then improved it through trial and error. Where the final result needed to be confirmed, additional tomographic inversion was conducted using the ray-tracing model as an initial model of inversion. The final velocity models in this study are the results of forward modeling, except for DAr5. The total length of DAr5 is $1,185 \mathrm{~km}$, the longest line in our exploration, and thus, we did not examine the model by forward modeling due to time limitations. In the last step, two-dimensional synthetic seismograms were calculated by the finite difference method, using the E3D code of Larsen and Schultz (1995), and compared with the observed amplitude variation in the record sections.

\section{Results}

The calculated Vp models discussed below are presented from north (the Amami Plateau) to south (the Oki-Daito Ridge). The Amami Plateau was transected by two north-south-oriented seismic lines (DAr2 and DAr5), whereas six lines were run across and along the Daito Ridge (ODr1, DAr2, ODr9, DAr5, DAr3, and DAr4). We also report Vp models for these north-south profiles, except for line DAr4, which does not transect the main body of the Daito Ridge. Seven seismic lines were shot across and along the Oki-Daito Ridge. However, since line ODr2 was too short to resolve the deeper part of the Oki-Daito Ridge, we only show results for OKr4, ODr1, and ODr9 for the northwestern part of the ridge and ODr5, DAr5, and KPr15 for the southwestern part.

Following Calvert (2011), we loosely divide our crustal models into three parts (upper, middle, and lower crusts) based on their velocities, velocity gradients, and thickness proportions, and subsequently describe their characteristics.

\section{Amami Plateau}

Figure 3 shows the $\mathrm{Vp}$ models along the north-south lines DAr5 and DAr2. DAr2 crosses the shallowest part of the region, where water depth only reaches approximately $1,550 \mathrm{~m}$. The record section, ray diagram, and synthetic seismogram for OBS 41 on DAr2 are shown in Figure 4. The fitting error between the observed and calculated first arrivals is less than about 50 ms. The crustal models in Figure 3 are strongly heterogeneous in horizontal direction, especially in the upper crust, with $\mathrm{Vp}$ of about 3.0 to $6.0 \mathrm{~km} / \mathrm{s}$. A middle crust characterized by $\mathrm{Vp}$ of 6.0 to $6.8 \mathrm{~km} / \mathrm{s}$ and a thickness of approximately 2 to $4 \mathrm{~km}$ is present beneath the plateau, except below the southern row of the bathymetric high along DAr2, where little material with a similar Vp exists. The middle crust in the western region of the plateau that contains greater water depths along DAr2 is relatively thin when compared with that in the eastern region along DAr5. Vp of the lower crust is 6.8 to $7.2 \mathrm{~km} / \mathrm{s}$.

PmP travel times infer a maximum depth of $19 \mathrm{~km}$ for the Moho discontinuity beneath the middle-plateau 


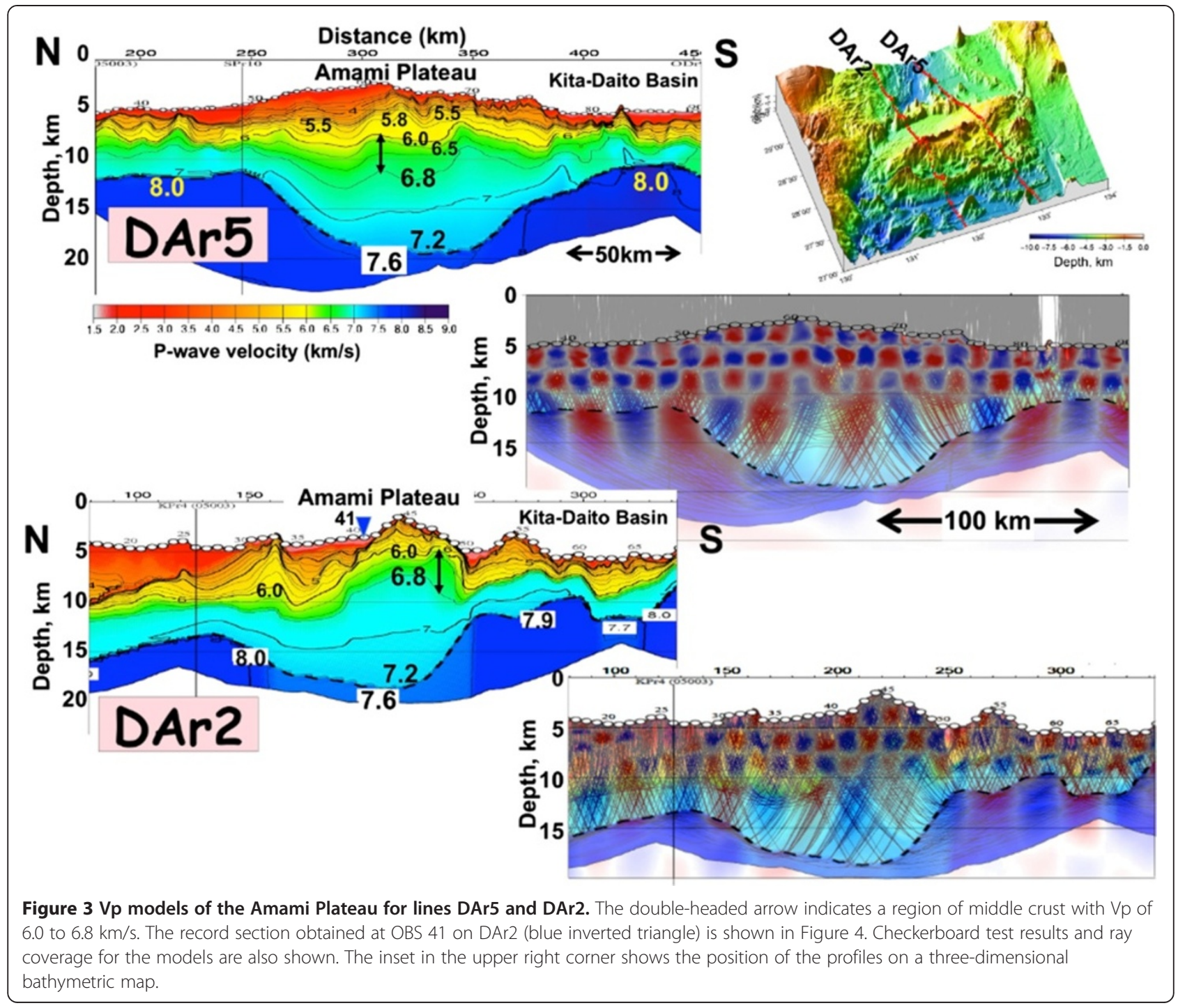

bathymetric high (Figure 4), whereas the crust below the southern high is the thinnest of the three rows. The Pn velocity immediately beneath the plateau is approximately $7.6 \mathrm{~km} / \mathrm{s}$ (significantly lower than $8 \mathrm{~km} / \mathrm{s}$ ), which is verified by both inversion and forward modeling. The synthetic seismograms in Figure 4c also explain both observed travel times and amplitude variation with an offset.

\section{Daito Ridge}

Figures 5 (top left) and 6a show the crust and uppermost mantle models beneath the north-south lines across the Daito Ridge, respectively. In addition to the Vp models, the checkerboard test results of tomographic inversion and the ray coverage are also shown in Figures 5 (bottom left) and $6 \mathrm{~b}$, respectively. The checkerboard pattern can be recovered down to a depth of $15 \mathrm{~km}$ under the ridge, with the deeper part determined mainly by forward modeling. We do not present a Vp model for DAr4 along the eastern thin ridge in this paper, but we have examined its consistency at the intersections with DAr5 and DAr3. Although the upper crust Vp, the depth of the Moho, and the Pn velocities are mostly consistent at these seismic line intersections, the velocity profiles of the middle and lower crust are different. This may be due to large horizontal heterogeneities in each crust; the structural model beneath ODr1 is shown in the next section for the Oki-Daito Ridge.

Despite the large heterogeneity among the Vp models for the DAr2, ODr9, DAr5, and DAr3 lines, a common characteristic of these velocity structures is another notable difference between the northern and southern parts of the ridge. A material with $\mathrm{Vp} \leq 6.3 \mathrm{~km} / \mathrm{s}$ and a thickness of 6 to $11 \mathrm{~km}$ is present in the southern region, while a material with $\mathrm{Vp} \geq 6.3 \mathrm{~km} / \mathrm{s}$ ascends to approximately 2 $\mathrm{km}$ from the seafloor in the northern region. 


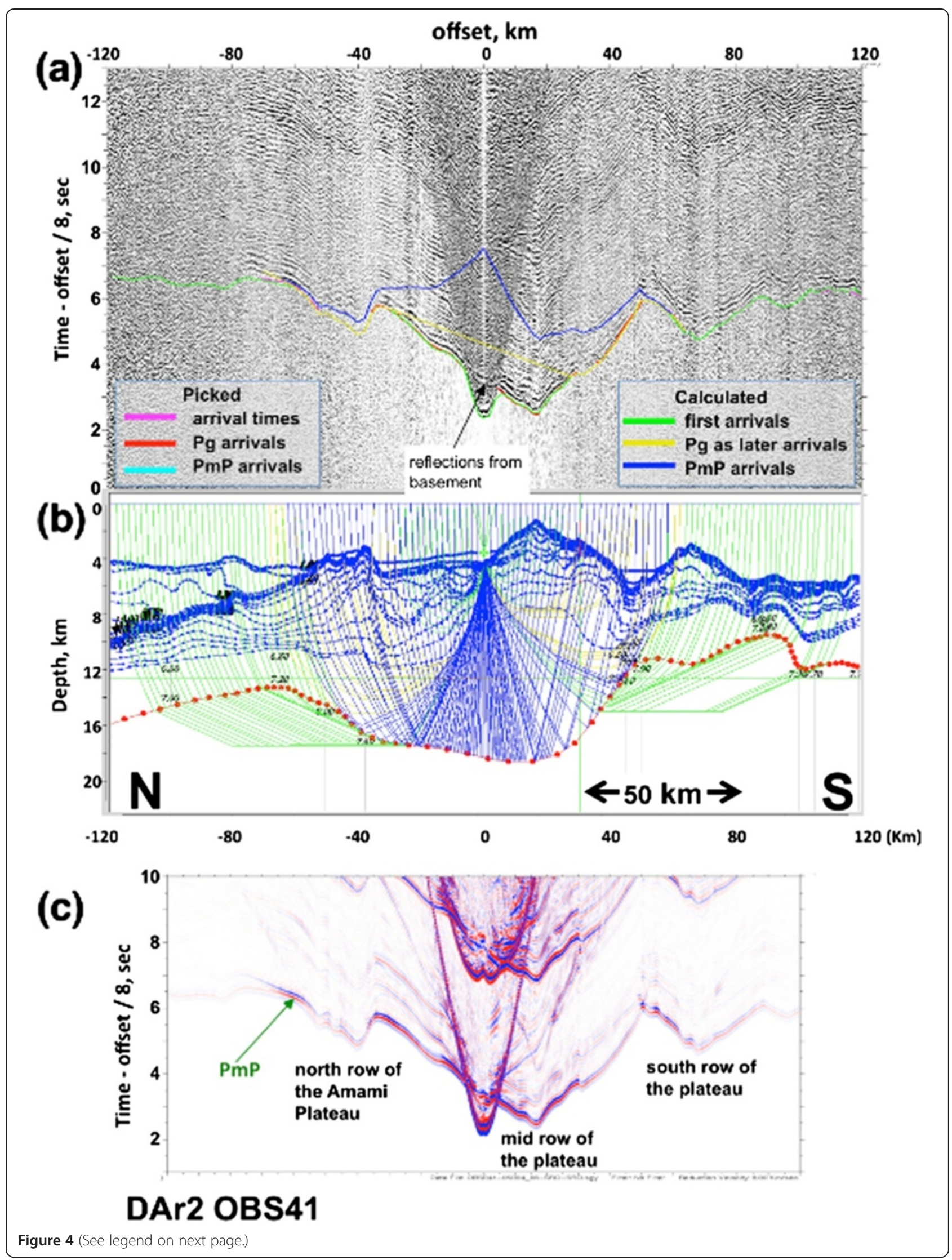


(See figure on previous page.)

Figure 4 Observed record section, ray diagram, and synthetic seismogram. (a) Observed record section for OBS 41 of line DAr2 on the Amami Plateau. The reduction velocity is $8 \mathrm{~km} / \mathrm{s}$. The arrival time readings and calculated travel times are shown on the record section. The calculated Pg arrivals between -30 and $30 \mathrm{~km}$ are artificial. (b) Ray diagram. (c) Synthetic seismogram.

Determining the velocity at the base of the crust can be difficult, but it is sometimes possible to estimate the velocity distribution in the entire crust effectively by using as many later phase arrivals as possible. The observed first and later arrivals are explained by forward modeling with a lower crust Vp of 7.0 to $7.2 \mathrm{~km} / \mathrm{s}$ (Figure $7 \mathrm{a}$, left). Vp of the uppermost mantle is 7.6 to $7.9 \mathrm{~km} / \mathrm{s}$, significantly lower than $8.0 \mathrm{~km} / \mathrm{s}$ beneath the bathymetric highs, which is consistent in the northern and southern regions of the Daito Ridge. Tomographic inversion with a broad Moho transition as an initial model resulted in an uppermost mantle $\mathrm{Vp} \leq 8 \mathrm{~km} / \mathrm{s}$. The crustal thickness varies between 13 and $20 \mathrm{~km}$ along the seismic lines and is generally thinner in the northern compared to the south for DAr2 and ODr9 beneath the western ridge, which corresponds to the difference in water depth. Regarding DAr5 and DAr3 in the eastern ridge with a narrow bathymetric high, the crustal thickness is the same for the north and south regions, and the crusts are thickest around the middle point of the ridge.

\section{Oki-Daito Ridge}

Six velocity profiles across the Oki-Daito Ridge in the broad sense are presented in this work. Three of them (DAr5, ODr5, and KPr15) intersect the bathymetric high at the southeastern Oki-Daito Ridge (Figure 8a), and the other three (OKr4, ODr9, and ODr1) transect the Oki-Daito Rise and Oki-Daito Plateau (Figure 9a). The checkerboard test results and ray diagram for each model are shown in Figures $8 b$ and $9 b$.

Figure 8a illustrates three $\mathrm{Vp}$ models across the two rows of linear bathymetric highs and a valley between them in the southeastern Oki-Daito Ridge. The three profiles transect a bathymetric high on the northern row, the

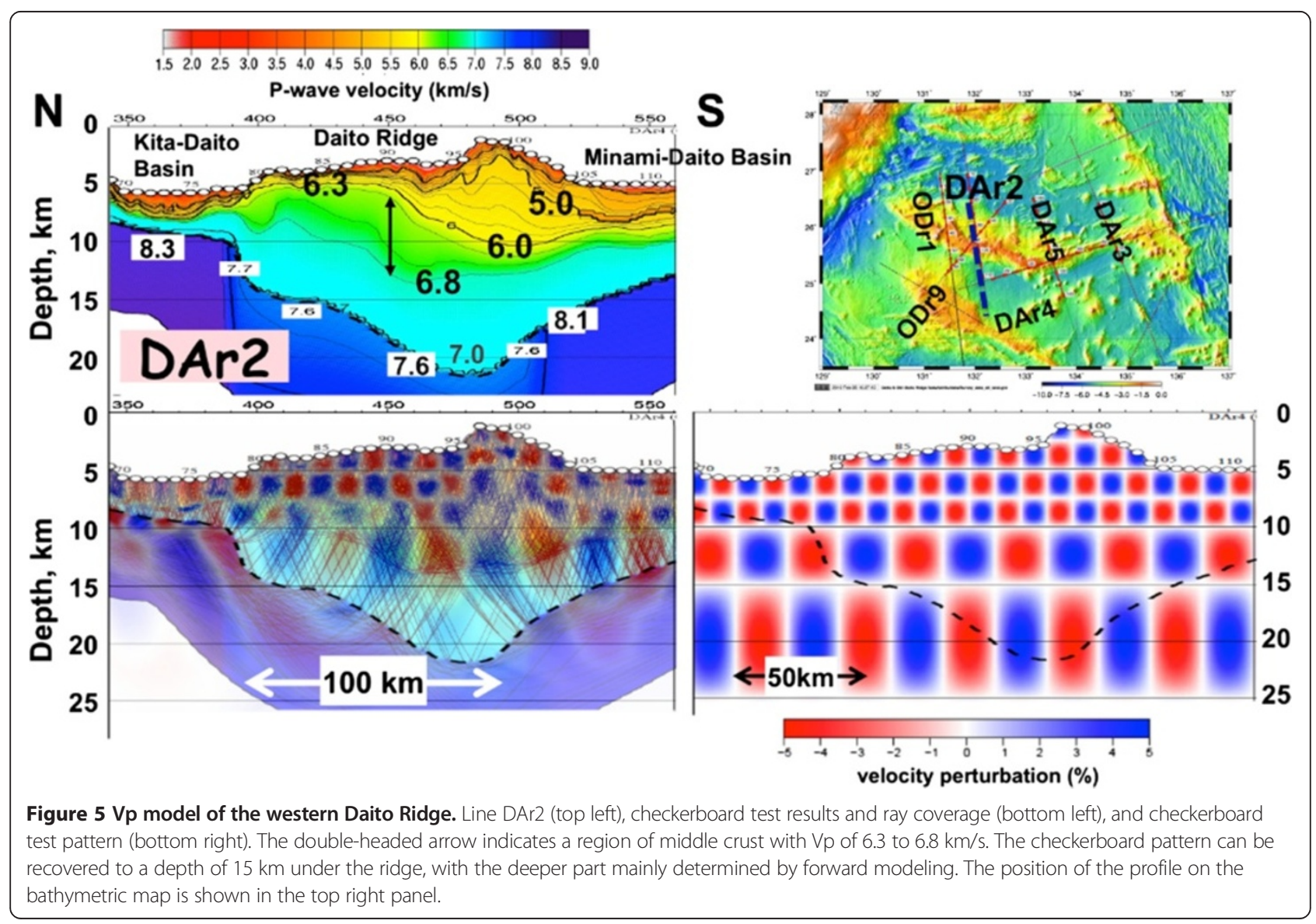




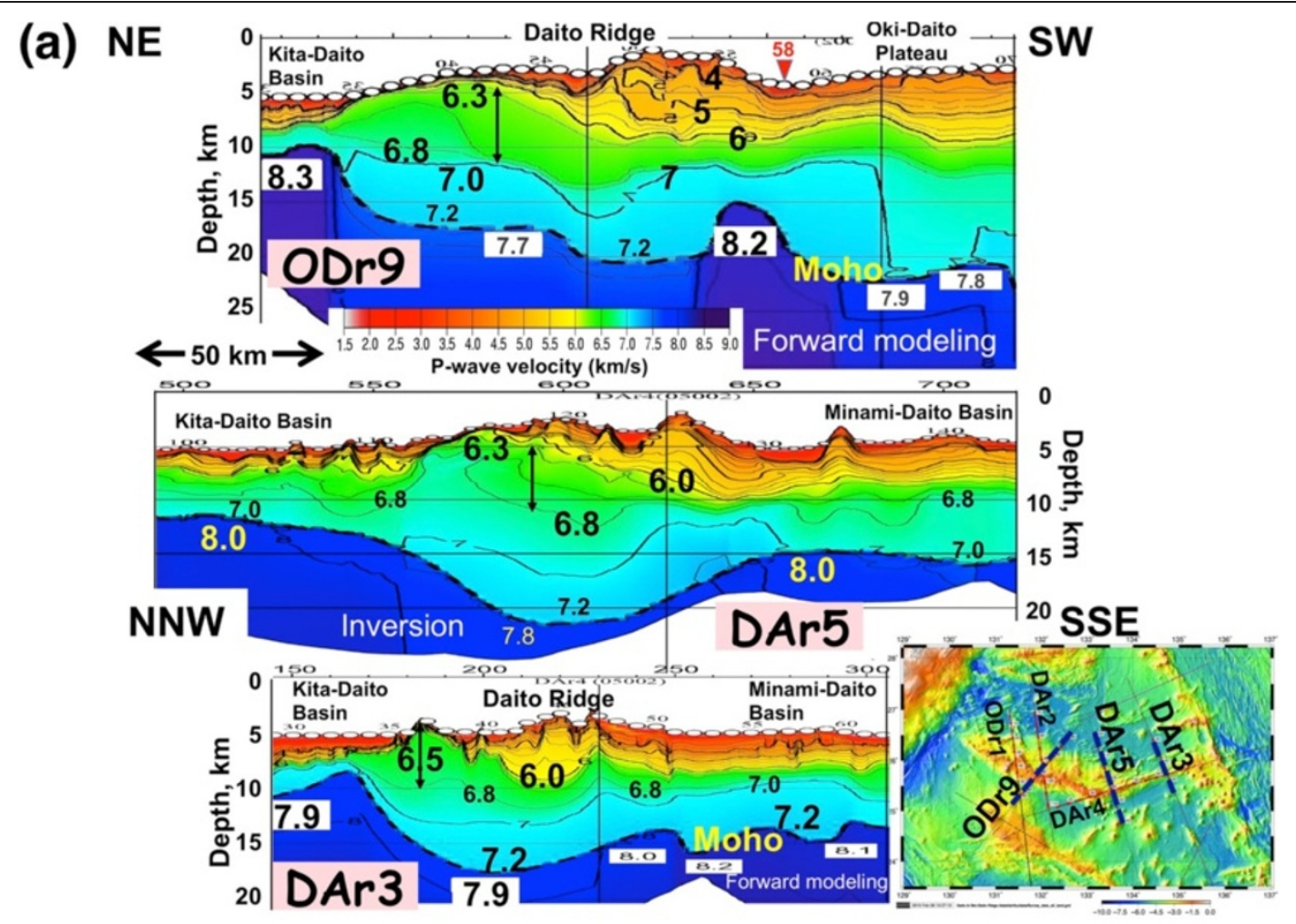

(b)

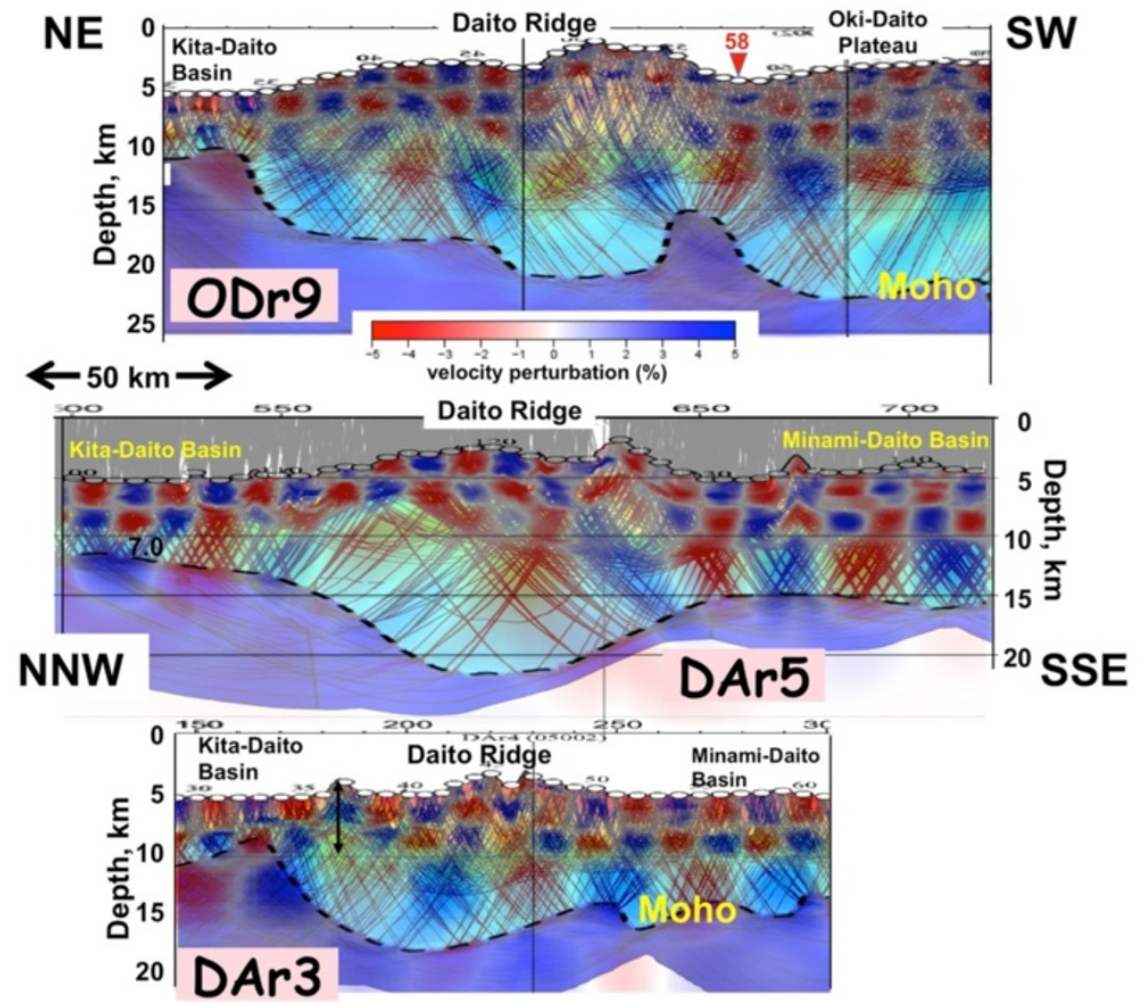

Figure $6 \mathrm{Vp}$ models of the Daito Ridge and checkerboard test results and ray coverage. (a) Vp models of the Daito Ridge for lines ODr9 (top), DAr5 (middle), and DAr3 (bottom). The double-headed arrow indicates a region of middle crust with Vp of approximately 6.3 to $6.8 \mathrm{~km} / \mathrm{s}$. The inset in the lower right corner shows the locations of the profiles on the bathymetric map. (b) Checkerboard test results and ray coverage for the Vp models of the Daito Ridge for lines ODr9 (top), DAr5 (middle), and DAr3 (bottom) that are shown in (a). 


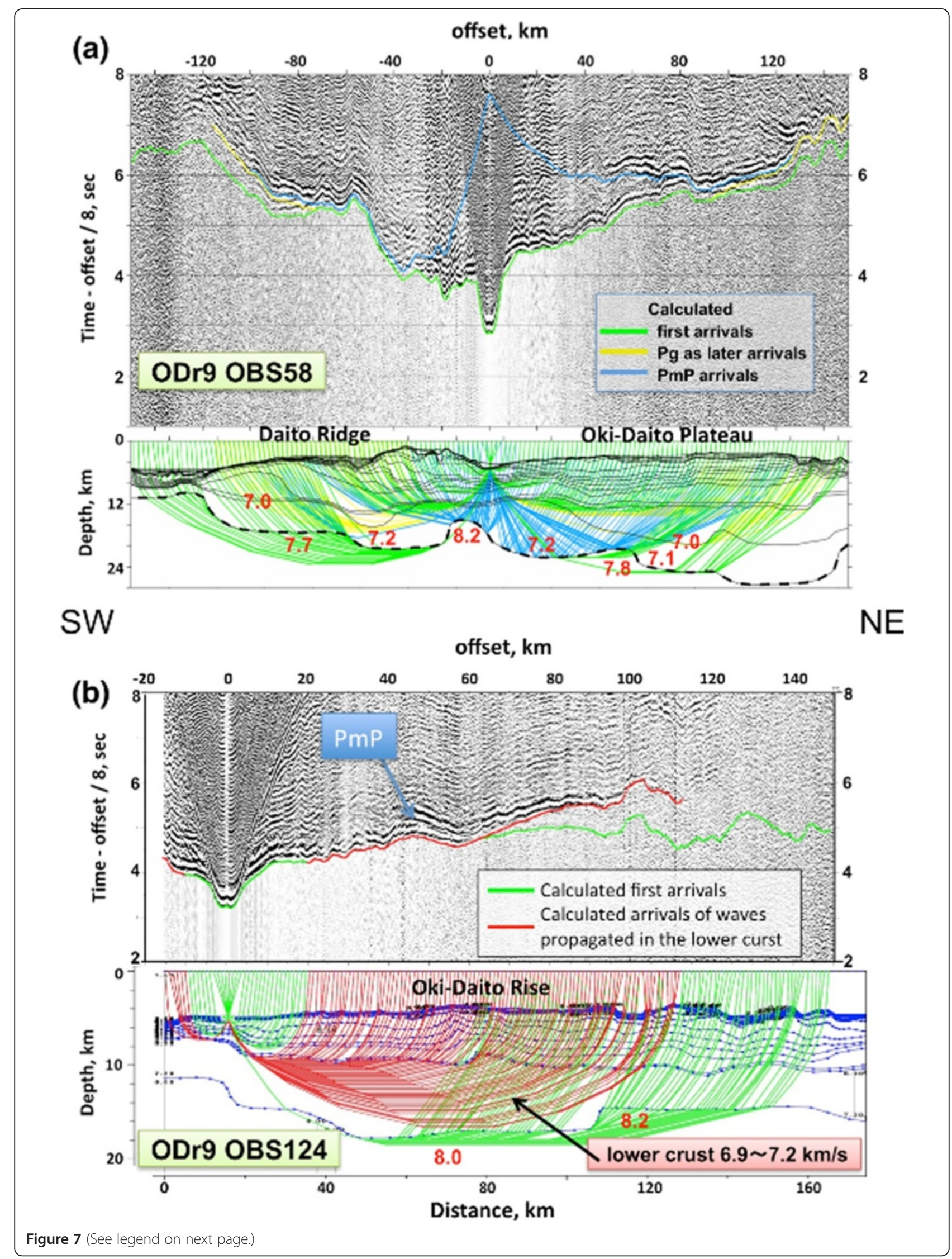


shallowest portion in the southeastern Oki-Daito Ridge. A common feature is the presence of a thick middle crust with $\mathrm{Vp}$ of 6.3 to $6.8 \mathrm{~km} / \mathrm{s}$ beneath the bathymetric high. The upper crust (with $\mathrm{Vp}$ of approximately 3.0 to $6.3 \mathrm{~km} / \mathrm{s}$ ) is slightly thicker beneath the valley. The thickness of the lower crust (with Vp of 6.8 to $7.2 \mathrm{~km} / \mathrm{s}$ ) is 7 to $10 \mathrm{~km}$, and the total crustal thickness is 20 to $30 \mathrm{~km}$. Although the Pn velocity is about $8.6 \mathrm{~km} / \mathrm{s}$ at the transition from the Oki-Daito Ridge and West Philippine Basin, the velocity below the ridge crest is 7.6 to $7.8 \mathrm{~km} / \mathrm{s}$. The high uppermost mantle velocity of about $8.6 \mathrm{~km} / \mathrm{s}$ seems to belong to the West Philippine Basin, which is horizontally and vertically heterogeneous and has a Pn velocity ranging from approximately 8.0 to $8.6 \mathrm{~km} / \mathrm{s}$ (Figure $8 \mathrm{a}, \mathrm{b}$ ).

$\mathrm{Vp}$ and the thickness of the uppermost sediment layer in the Oki-Daito Plateau are 1.8 to $2.2 \mathrm{~km} / \mathrm{s}$ and about 1 $\mathrm{km}$, respectively (Figure 9a). The upper crust has Vp of about 3.0 to $6.3 \mathrm{~km} / \mathrm{s}$ and a thickness of 3 to $7 \mathrm{~km}$. Underlying the upper crust, there is a middle crust with $\mathrm{Vp}$ of 6.3 to $6.8 \mathrm{~km} / \mathrm{s}$ and a thickness of 3 to $5 \mathrm{~km}$, and a lower crust with $\mathrm{Vp}$ of 6.8 to $7.2 \mathrm{~km} / \mathrm{s}$ and a thickness of 10 to $15 \mathrm{~km}$. The Pn velocity here is 7.7 to $7.9 \mathrm{~km} / \mathrm{s}$, and the total crustal thickness is 20 to $25 \mathrm{~km}$. These characteristics are similar to those of the Daito Ridge.

Clear large-amplitude PmP signals were observed in the record sections of many OBSs installed on the plateau. Later phases with comparable large amplitude were frequently recorded at larger offsets (e.g., Figure 10b), which makes the identification of PmP difficult. We interpreted the shallower reflector as the Moho discontinuity and the deeper one as a reflector in the uppermost mantle, 5 to 10 $\mathrm{km}$ below the Moho discontinuity.

The middle crust of the Oki-Daito Rise is thin compared to that at other bathymetric highs in this region (Figure 9a). The Vp distribution in the crust is well-constrained, as shown in Figure $7 \mathrm{~b}$, and $\mathrm{Vp}$ at the crust bottom is estimated to be $7.2 \mathrm{~km} / \mathrm{s}$. The total maximum crustal thickness of $14 \mathrm{~km}$ is also thinner compared with other ridges in this region. The Pn velocity is $7.8 \mathrm{~km} / \mathrm{s}$ in the northern part of the rise along OKr4 (Figure 9a, top), but a higher Pn velocity $(\geq 8.0 \mathrm{~km} / \mathrm{s}$ ) was measured along ODr9 (Figure 9a, center) and the southern rise along $\mathrm{OKr} 4$.

OBSs deployed on the Oki-Daito Plateau and Oki-Daito Rise frequently recorded large-amplitude signals over distances of about $180 \mathrm{~km}$. Figure 10 shows examples of the record sections obtained at OBS 58 and 115 on ODr9. When considering these signals as first arrivals, we were unable to construct a $\mathrm{Vp}$ model to account for these travel times; thus, we interpreted the travel times as reflection signals and estimated the position of the reflector using the travel time mapping method of Fujie et al. (2006). The reflector was denoted with a white line in Figure 10c. In addition to the mapping, we examined the reflector position and $\mathrm{Vp}$ distribution by forward modeling. Assuming a rough estimate of the mantle velocity and a reflector extending for 110 to $290 \mathrm{~km}$ along ODr9 (Figure 10c), we were able to explain the observed travel times with an error of less than $0.2 \mathrm{~s}$ (except at offset 210 to $240 \mathrm{~km}$ for OBS 115, where the error was $0.3 \mathrm{~s}$ ). Finally, we compared the observed record sections with synthetic seismograms and confirmed large amplitude signals at offsets of over $180 \mathrm{~km}$. That is, a velocity discontinuity at a depth of about $45 \mathrm{~km}$ under the plateau is proposed as one of possible interpretations for these signals. Furthermore, similar reflection signals were recorded by several OBSs at $\mathrm{OKr} 4$. In the same way, we estimated the position of the interface at a depth of about $50 \mathrm{~km}$ with a horizontal width of about $60 \mathrm{~km}$ beneath the Oki-Daito Rise.

\section{Discussion and conclusion}

We have compiled Vp structural models from ten wideangle seismic lines in the Daito Ridges region at the northwestern end of the Philippine Sea plate. The crustal models obtained for the Amami Plateau (Figure 3) and the Daito Ridge (Figures 5 and 6a) are similar. In both cases, there is an upper crust with Vp of 3.0 to $6.3 \mathrm{~km} / \mathrm{s}$ and a middle crust with $\mathrm{Vp}$ of 6.3 to $6.8 \mathrm{~km} / \mathrm{s}$ below the ridges, although their relative proportions vary along the seismic lines. The lower crust and upper mantle seismic velocities are 6.8 to 7.2 and 7.6 to $7.9 \mathrm{~km} / \mathrm{s}$, respectively. The maximum crustal thickness beneath the bathymetric highs reaches approximately $20 \mathrm{~km}$.

The Kita-Daito Basin is situated between the Amami Plateau and Daito Ridge (Figure 1) and has a thin crust of 4 to $6 \mathrm{~km}$, as deduced from its seismic structure (Nishizawa et al. 2013). The top of the middle crust of the Amami Plateau (Figure 3) tends to shallow southward of the Kita-Daito Basin, particularly in the mid-row bathymetric high along DAr2. A notable feature of the Daito Ridge crust is that a material with $\mathrm{Vp} \leq 6.3 \mathrm{~km} / \mathrm{s}$ and a thickness of 6 to $11 \mathrm{~km}$ is concentrated in the southern part, while a material with $\mathrm{Vp} \geq 6.3 \mathrm{~km} / \mathrm{s}$ ascends closer to the seafloor toward the Kita-Daito Basin in the north. The middle crust beneath both the Amami Plateau and the Daito Ridge shallows towards the Kita-Daito Basin, which 
(a)
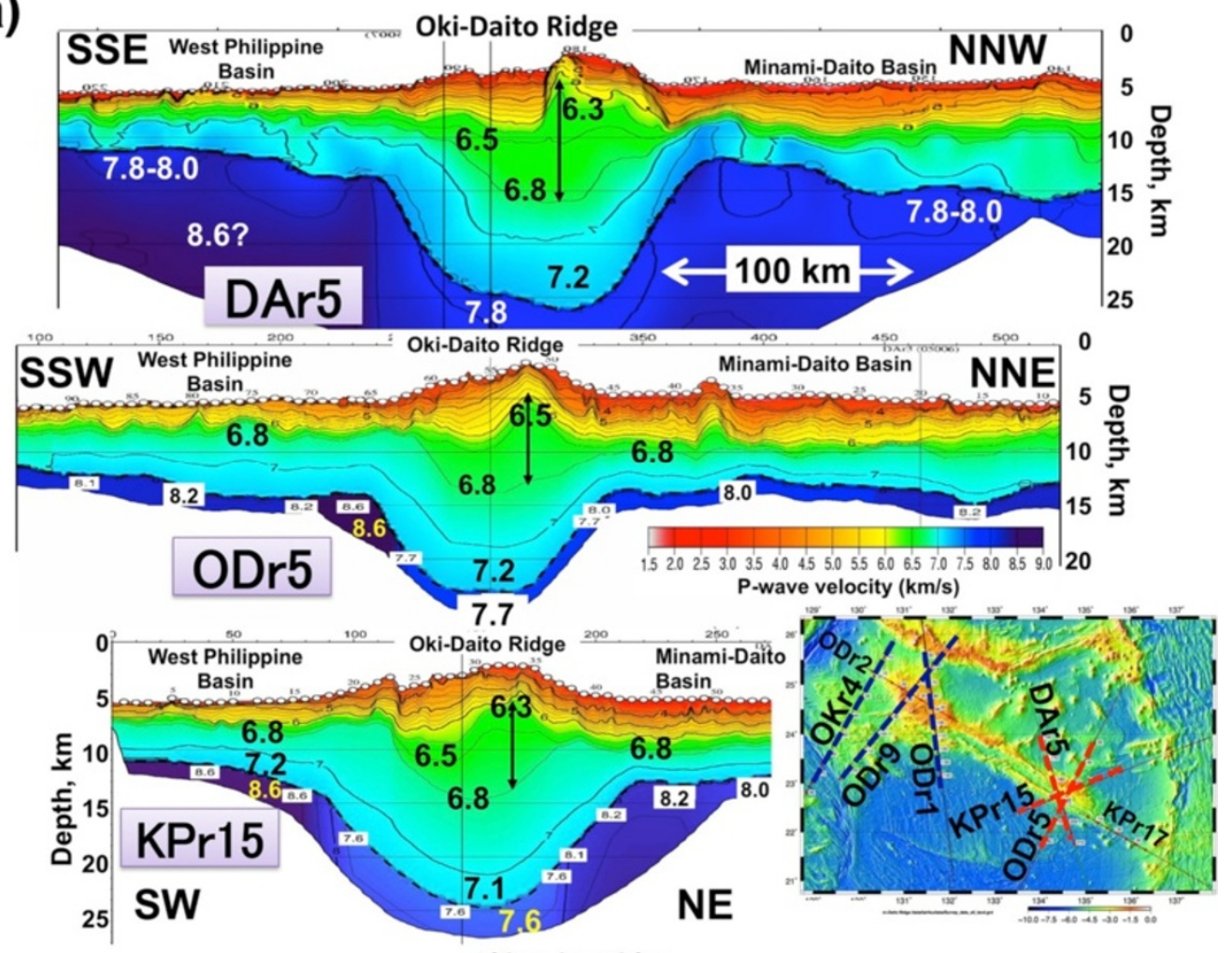

(b)
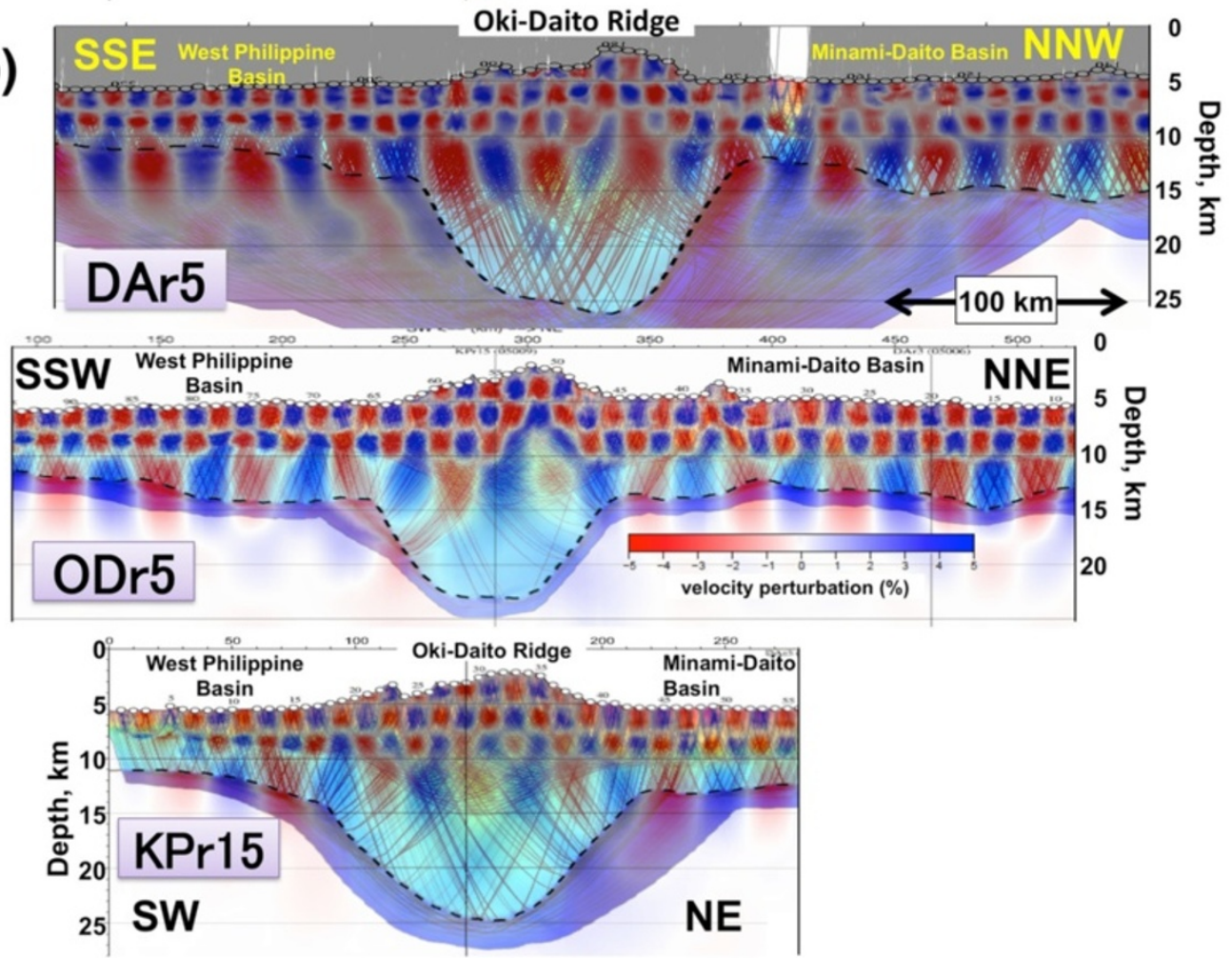

Figure 8 Vp models and checkerboard test results. (a) Vp models of the southeastern Oki-Daito Ridge for lines DAr5 (top), ODr5 (middle), and KPr15 (bottom). The double-headed arrow indicates the thickest region of the middle crust with Vp of approximately 6.3 to $6.8 \mathrm{~km} / \mathrm{s}$ for each profile. The inset in the lower right corner shows the locations of the profiles (red dashed lines) on the bathymetric map. (b) Checkerboard test results and ray coverage for Vp models of the southeastern Oki-Daito Ridge for lines DAr5 (top), ODr5 (middle), and KPr15 (bottom) that are shown in (a). 


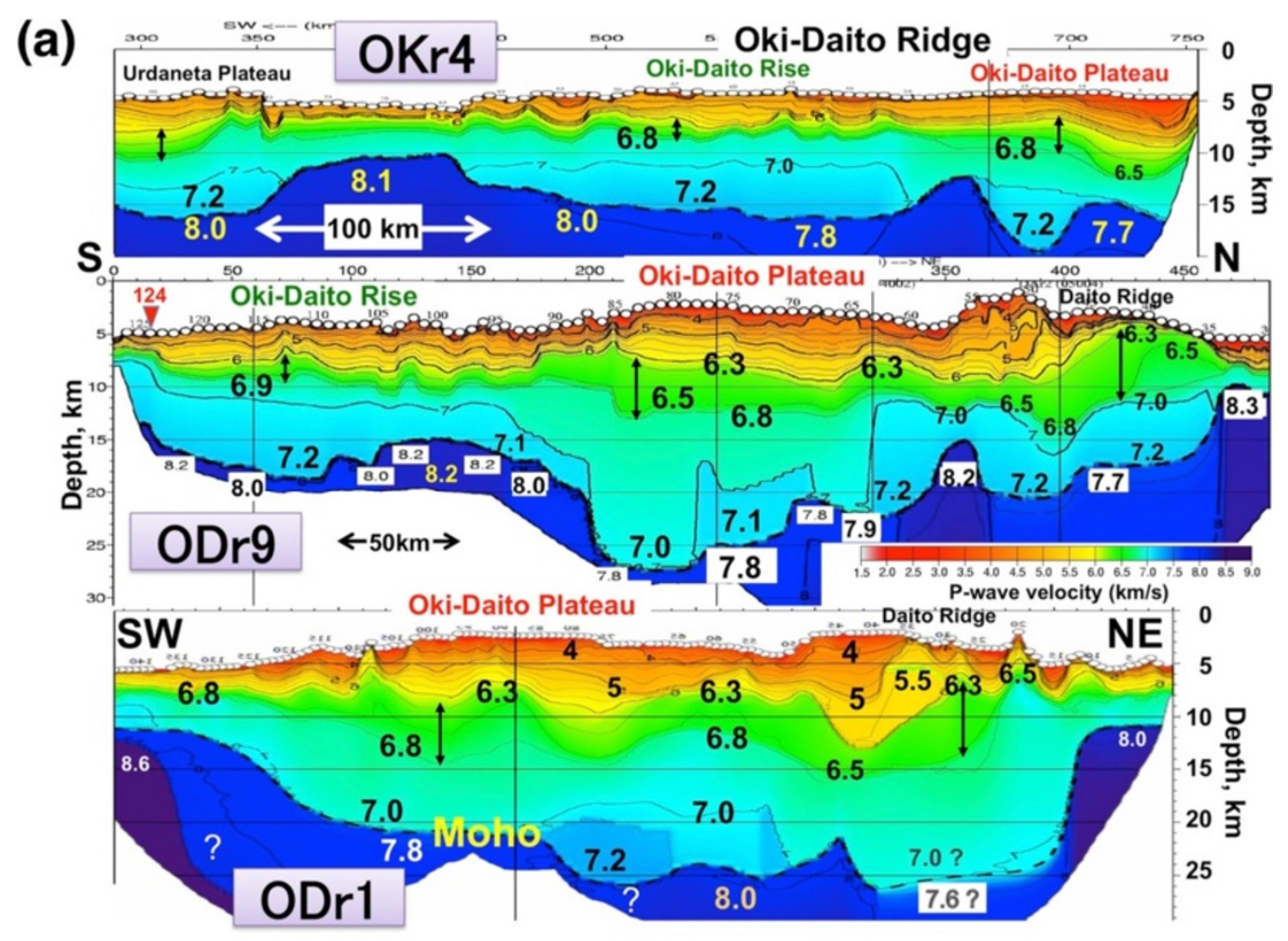

(b)

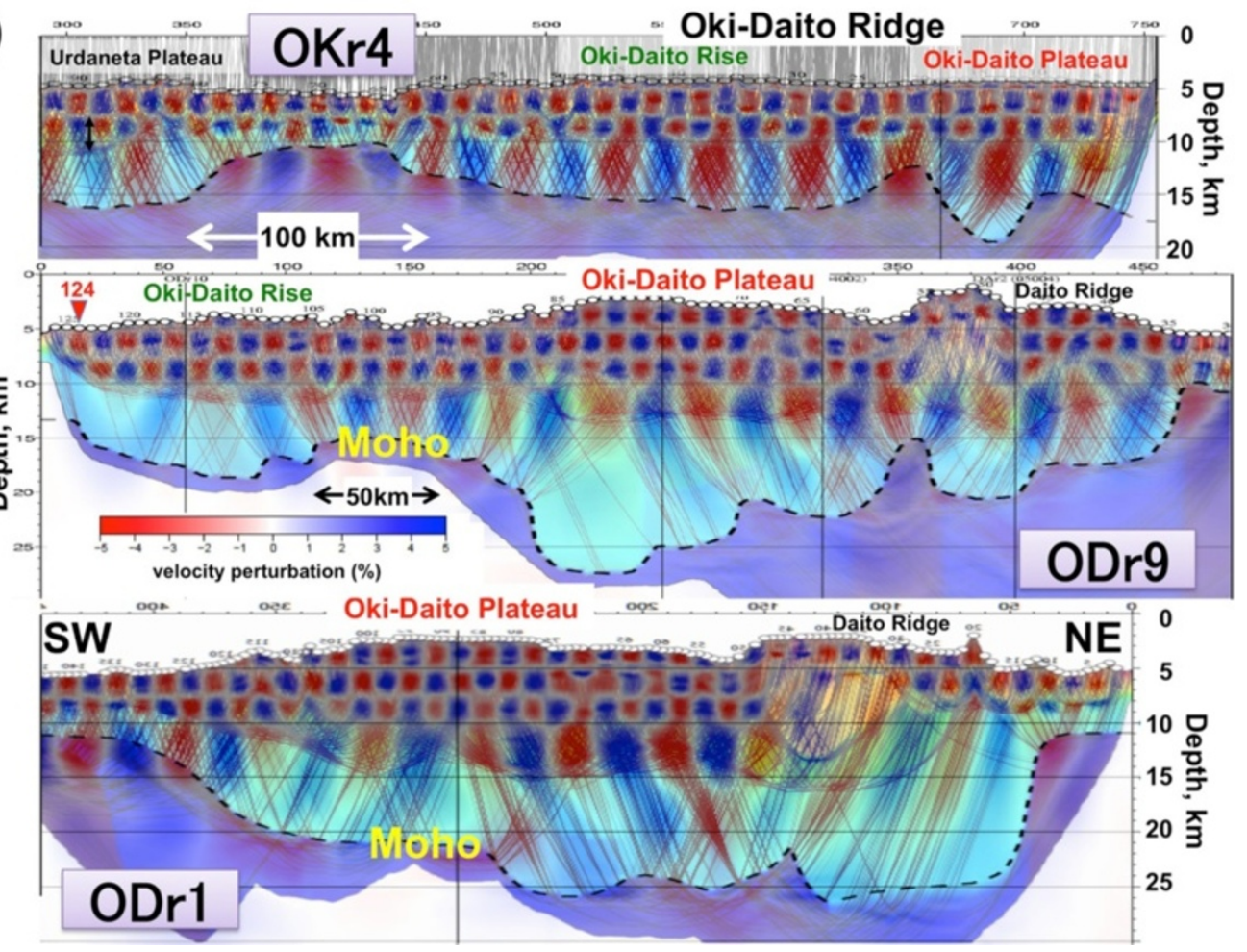

Figure $9 \mathrm{Vp}$ models, checkerboard test results, and ray coverage. (a) Vp models across the northwestern Oki-Daito Ridge in the broad sense for lines OKr4 (top), ODr9 (middle), and ODr1 (bottom). The double-headed arrow indicates a middle crust with Vp of approximately 6.3 to $6.8 \mathrm{~km} / \mathrm{s}$ for each profile. The positions of the seismic profiles are indicated by blue dashed lines in the lower right corner in Figure 8a. (b) Checkerboard test results and ray coverage for Vp models across the northwestern Oki-Daito Ridge in the broad sense for lines OKr4 (top), ODr9 (middle), and ODr1 (bottom) that are shown in (a). 


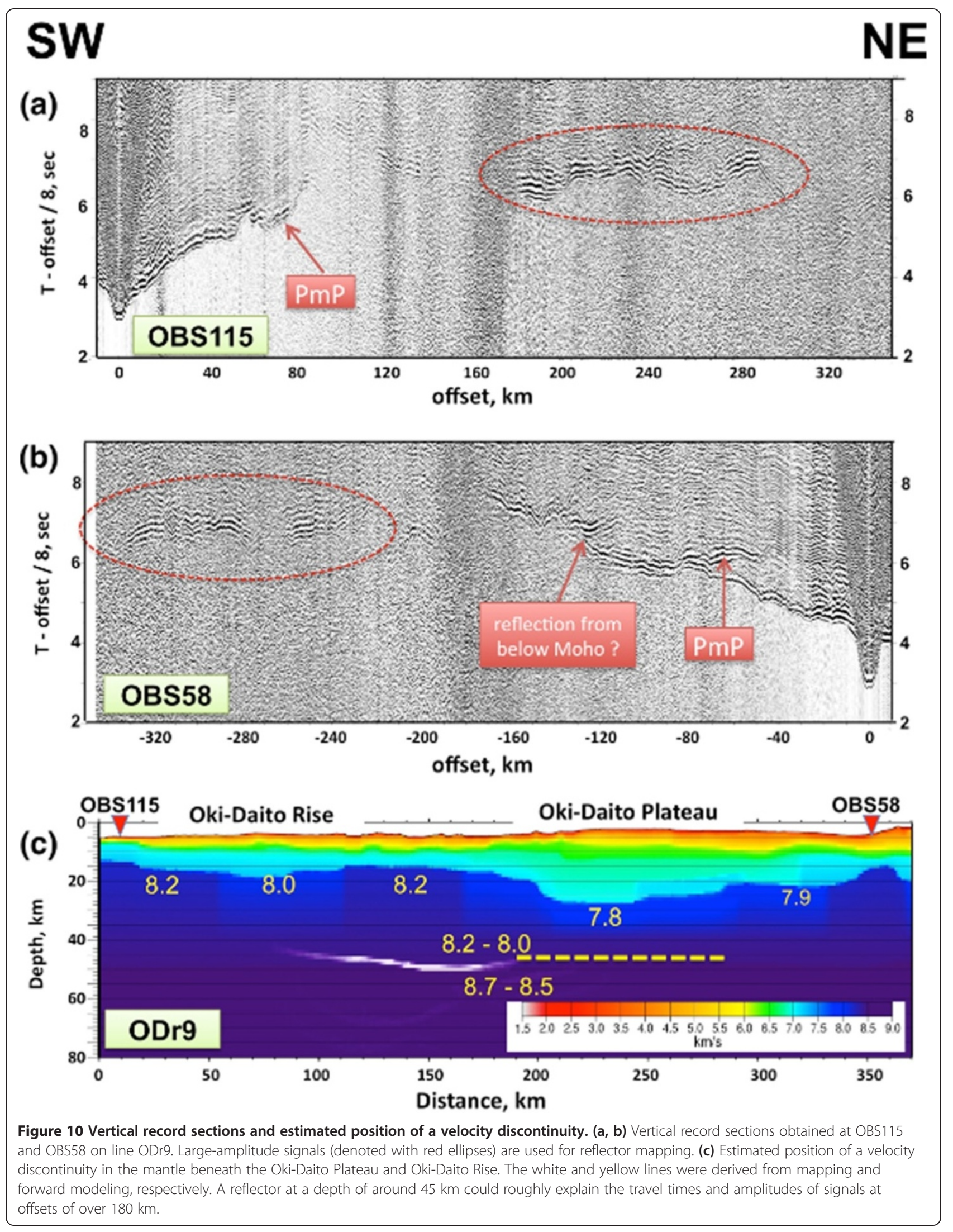


may be the result of extension between the two bathymetric highs. However, instead of an ascending middle crust, Canales et al. (2008) report that a deeper crust consisting predominantly of gabbro was exhumed at several oceanic core complexes, which are large-offset normal fault systems commonly referred to as oceanic detachment faults on the Mid-Atlantic Ridge.

A much thinner crust, with a thickness of approximately $3 \mathrm{~km}$ and a high Pn velocity of $8.3 \mathrm{~km} / \mathrm{s}$, occurs at the transition from the Daito Ridge to the Kita-Daito Basin. This crust shows the same characteristics as that found at the transition between the Kyushu-Palau Ridge and the Shikoku and Parece Vela Basins, where backarc spreading had occurred (Nishizawa et al. 2012). The Vp model of the Kita-Daito Basin suggests the presence of a thinner crust, similar to the backarc basin oceanic crust in the Shikoku and Parece Vela Basins, as revealed by Nishizawa et al. (2011, 2013). These features lend credence to the interpretation of rifting and seafloor spreading between the Amami Plateau and Daito Ridge, which is supported further by roughly east-west aligned magnetic anomalies in the Kita-Daito Basin (Figure 2c) that imply seafloor spreading in the north-south direction. By contrast, Kasuga et al. (1986) interpreted these lineations to be related to topographic relief. Moreover, although Tokuyama et al. (1986) proposed that the backarc spreading of the Kita-Daito Basin was caused by subduction at the southern edge of the Daito Ridge, our seismic profiles do not contain any distinctive features indicative of subduction.

Individually, $\mathrm{Vp}$ models for the three sub-regions of the Oki-Daito Ridge in the broad sense reveal different features (Figures 8a and 9a). The Oki-Daito Plateau has the thickest crust (20 to $25 \mathrm{~km}$ ) of these sub-regions (Figure 9a). This comprises an upper crust with Vp of approximately 3.0 to $6.3 \mathrm{~km} / \mathrm{s}$, a middle crust with $\mathrm{Vp}$ of 6.3 to $6.8 \mathrm{~km} / \mathrm{s}$, and a lower crust with $\mathrm{Vp}$ of 6.8 to 7.2

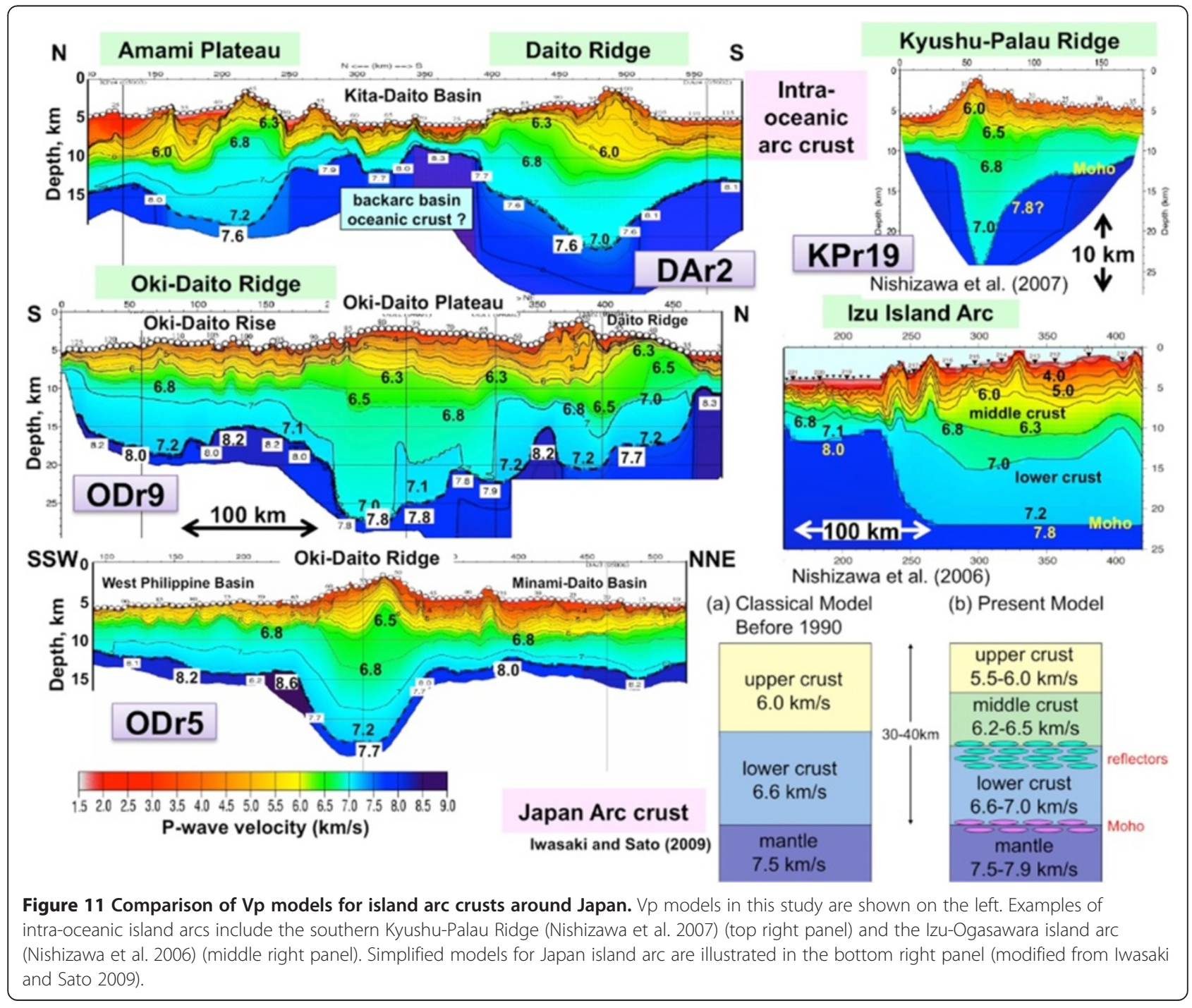


$\mathrm{km} / \mathrm{s}$, which is a similar structure to that of the Daito Ridge crust. In contrast, the Oki-Daito Rise in the southwestern part of the ridge has a relatively thin middle crust, reaching a maximum total crustal thickness of 14 $\mathrm{km}$, which is different from other bathymetric highs in the Daito Ridges as well as from typical oceanic crust.

A deep reflector was identified at approximately $45 \mathrm{~km}$ below the sea floor between the Oki-Daito Rise and Plateau (Figure 10). The detection of such deep reflectors requires a sufficiently long seismic line as well as closely placed shots and receivers, although we do not presently have sufficient data to discern the spatial distribution of these reflectors in the Daito Ridges region. In addition, most seismic refraction lines performed in previous studies did not reach the required offsets. Kaneda et al. (2010) found deeper reflectors at a depth of 35 to $45 \mathrm{~km}$ beneath seamounts with a hot spot origin in the northwestern Pacific Basin. They inferred that these reflectors indicate structures that formed via intraplate igneous activities, such as at the top of a mantle partial melting zone or a remnant of a hot spot plume head. OIB rock samples obtained from the Oki-Daito Ridge in the broad sense were different from the samples collected from the Amami Plateau and Daito Ridge (e.g., Ishizuka et al. 2013). The existence of a deep reflector may therefore indicate intraplate volcanic activity in this region, although further investigation is required in order to confirm this interpretation.

The Oki-Daito Ridge shows a narrower ridge topography compared to the Oki-Daito Plateau and the Oki-Daito Rise; however, it has a thicker crust of 20 to $23 \mathrm{~km}$ (Figure 8a). The top of the middle crust, which has $\mathrm{Vp}$ of 6.3 to 6.8 $\mathrm{km} / \mathrm{s}$, is shallower beneath the northeastern bathymetric high. Slightly thinner crust and a notably higher Pn velocity were measured at the boundary between the ridge and the Minami-Daito Basin to the north along the KPr15 and DAr5 seismic lines. Apparently, a similar structure was found at the north of the Daito Ridge, where rifting is inferred. However, neither thin crust nor high Pn velocities were clearly observed at the transition from the MinamiDaito Basin along ODr5. The Pn velocity obtained beneath the Minami-Daito Basin varies between around 7.7 and 8.2 $\mathrm{km} / \mathrm{s}$ and is locally higher than $8.0 \mathrm{~km} / \mathrm{s}$ (Nishizawa et al. 2013). Therefore, the shallower and thicker middle crust beneath the northeastern side of the ridge may be related to the bathymetric high that was presumably produced by OIB activity 44 to $48 \mathrm{Ma}$ ago (Ishizuka et al. 2013). While the linear valley topography suggests rifting along the ridge, the velocity models do not show obvious axial symmetry. To confirm this feature, additional profiles across the ridge with symmetrical seafloor topography are needed.

Although large variations in crustal structure exist across the study area, though the crustal model for the Oki-Daito Rise constitutes an exception, we can summarize our results as follows. The Vp models obtained for the bathymetric highs in the Daito Ridges region generally correspond to a middle crust with Vp of 6.3 to $6.8 \mathrm{~km} / \mathrm{s}$, a lower crust with Vp of 6.8 to $7.2 \mathrm{~km} / \mathrm{s}$, a Pn velocity of 7.6 to $7.8 \mathrm{~km} / \mathrm{s}$, and a total crustal thickness of 15 to $25 \mathrm{~km}$. Rock samples obtained from these Daito Ridges bathymetric highs indicate that most of them have originated from island arcs (e.g., Hickey-Vargas 2005; Ishizuka and Yuasa 2007; Ishizuka et al. 2013).

There remains the question of whether our $\mathrm{Vp}$ models yield characteristics similar to the Japan island arc. Before 1990, the Japan island arc crust was considered to be composed of two layers, but it is currently divided into three parts owing to recent progress in observation and data analysis (Iwasaki and Sato 2009; right bottom panel in Figure 11). Iwasaki and Sato (2009) revealed that the crust of the Japan islands is composed of an upper part with a large $\mathrm{Vp}$ range of 5.5 to $6.1 \mathrm{~km} / \mathrm{s}$, a middle part with $V p$ of 6.2 to $6.5 \mathrm{~km} / \mathrm{s}$, and a lower part with $V p$ of 6.6 to $7.0 \mathrm{~km} / \mathrm{s}$. Furthermore, the Japan island arc crust has a lower crust $\mathrm{Vp}<7.0 \mathrm{~km} / \mathrm{s}$, a low Pn velocity of 7.5 to 7.9 $\mathrm{km} / \mathrm{s}$, and a total crustal thickness of 30 to $40 \mathrm{~km}$; thus, the middle and lower crusts have a significantly lower $\mathrm{Vp}$ than those of the Daito Ridges. Moreover, the Japan island arc has a much thicker crust, which indicates that it is a more mature island arc when compared to the Daito Ridges.

In contrast, the Vp structure of the IBM island arc (an immature intra-oceanic island arc) is characterized by a middle crust with $\mathrm{Vp}$ of 6.0 to $6.8 \mathrm{~km} / \mathrm{s}$, a lower crust with $\mathrm{Vp} \geq 7.0 \mathrm{~km} / \mathrm{s}$ at its base, and an uppermost mantle with $\mathrm{Vp}<8.0 \mathrm{~km} / \mathrm{s}$ (e.g., Suyehiro et al. 1996; Nishizawa et al. 2006; Takahashi et al. 2007). We compared our Vp models for the Daito Ridges with those for several intra-oceanic island arcs near Japan (Figure 11). The Vp models of the Daito Ridges show a closer match to those of the IBM arc and Kyushu-Palau Ridge, which are immature paleo-island arcs, than they do to those of the mature Japan island arc. Moreover, the velocities of the middle and lower crusts are not as high as those of the Aleutian arc, which may be a result of extension and rifting in this region (Calvert 2011). Future studies on $S$ wave velocity structure are expected to provide more information about the material properties of these paleo-island arcs.

\section{Competing interests}

The authors declare that they have no competing interests.

\section{Authors' contributions}

$\mathrm{AN}, \mathrm{KK}, \mathrm{YK}$, and $\mathrm{MO}$ contributed to the analysis and interpretation of the seismic data. AN compiled the regional tectonic information and drafted the manuscript. All authors read and approved the final manuscript.

\section{Acknowledgements}

The authors gratefully acknowledge Prof. Emeritus J. Kasahara, Dr. R. Kubota, and the members of the Continental Shelf Surveys Co. Ltd. for the data 
processing and analysis. Discussions with Y. Ohara, K. Tani and T. Morishita were valuable. We thank the two anonymous reviewers for their insightful comments. The authors are also grateful to the members of the Hydrographic and Oceanographic Department, JCG for the management of the seismic surveys.

Received: 2 July 2013 Accepted: 5 November 2013 Published: 30 April 2014

\section{References}

Calvert AJ (2011) The seismic structure of island arc crust. In: Brown D, Ryan PD (ed) Arc-continent collision. Frontiers in Earth Sciences. Springer, Heidelberg, pp 87-119. doi:10.1007/978-3-540-88558-0_4

Canales JP, Tucholke BE, Xu M, Collins JA, DuBois DL (2008) Seismic evidence for large-scale compositional heterogeneity of oceanic core complexes. Geochem Geophys Geosyst 9:1-22. doi:10.1029/2008GC002009

Deschamps A, Lallemand S (2002) The West Philippine Basin: an Eocene to early Oligocene back arc basin opened between two opposed subduction zones. J Geophys Res. doi:10.1029/2001JB001706

Fujie G, Kasahara J, Sato T, Mochizuki K (2000) Traveltime and raypath computation: a new method in a heterogeneous medium. J Soc Explor Geophys Jpn 53:1-11

Fujie G, Ito A, Kodaira S, Takahashi N, Kaneda Y (2006) Confirming sharp bending of the Pacific plate in the northern Japan trench subduction zone by applying a traveltime mapping method. Phys Earth Planet Inter 157:72-85. doi:10.1016/.jpepi.2006.03.013

Hickey-Vargas R (2005) Basalt and tonalite from the Amami Plateau, northern West Philippine Basin: new Early Cretaceous ages and geochemical results, and their petrologic and tectonic implications. Island Arc 14:653-665

Ishihara T, Koda K (2007) Variation of crustal thickness in the Philippine Sea deduced from three-dimensional gravity modeling. Island Arc 16:322-337

Ishizuka O, Yuasa M (2007) Age and geochemical characteristics of the igneous rocks recovered the Philippine Sea and Ogasawara Plateau area as a part of basic researches on exploration technologies for deep-sea natural resources. Rep on Deep Sea Survey Technology for Natural Resources in Japan, JOGMEC, Tokyo, pp 255-296

Ishizuka O, Taylor RN, Ohara Y, Yuasa M (2013) Upwelling rifting and age-progressive magmatism from the Oki-Daito mantle plume. Geology 41(9):1011-1014. doi:10.1130/G34525.1

Iwasaki T, Sato H (2009) Crust and uppermantle structure of island arc being elucidated from seismic profiling with controlled sources in Japan. J Seism Soc Jpn (Zisin) 61:S165-S176. Japanese with English abstract

Kaneda K, Kodaira S, Nishizawa A, Morishita T, Takahashi N (2010) Structural evolution of preexisting oceanic crust through intraplate igneous activities in the Marcus Wake seamount chain. Geochem Geophys Geosyst 11, Q10014. doi:10.1029/2010GC003231

Kasuga S, Koyama K, Kaneko Y (1986) Geomagnetic and gravity anomalies around the Daito Ridge. Rept Hydrogrp Res 21:65-76. Japanese with English abstract

Kobayashi K, Kasuga S, Okino K (1995) Shikoku basin and its margins. In: Taylor B (ed) Backarc basins: tectonics and magmatism. Plenum, New York, pp 381-405

Korenaga J, Holbrook WS, Kent GM, Kelemen PB, Detrick RS, Larsen HC, Hopper JR, Dahl-Jensen T (2000) Crustal structure of the southeast Greenland margin from joint refraction and reflection seismic tomography. J Geophys Res 105:21591-21614. doi:10.1029/2000JB900188

Kubota R, Nishiyama E, Murase K, Kasahara J (2009) Traveltime estimation of first arrivals and later phases using the modified graph method for a crustal structure analysis. Explor Geophys 40:105-113

Larsen SC, Schultz CA (1995) ELAS3D: 2D/3D elastic finite-difference wave propagation code. Lawrence Livermore National Laboratory technical report no. UCRL-MA-121792, p 19

Murauchi S, Den N, Asano S, Hotta H, Yoshii T, Asanuma T, Hagiwara K, Ichikawa K, Sato T, Ludwig WJ, Ewing Jl, Edgar NT, Houtz RE (1968) Crustal structure of the Philippine Sea. J Geophys Res 73:3143-3171

Nishizawa A, Suyehiro K, Shimizu H (1983) Seismic refraction experiment at the Amami Plateau. J Phys Earth 31:159-171

Nishizawa A, Kaneda K, Nakanishi A, Takahashi N, Kodaira S (2006) Crustal structure of the ocean-island arc transition at the mid Izu-Ogasawara (Bonin) arc margin. Earth Planets Space 58:e33-e36
Nishizawa A, Kaneda K, Katagiri Y, Kasahara J (2007) Variation in crustal structure along the Kyushu-Palau Ridge at 15-21 N on the Philippine Sea plate based on seismic refraction profile. Earth Planets Space 59:e17-e20

Nishizawa A, Kaneda K, Oikawa M (2009) Seismic structure of the northern end of the Ryukyu Trench subduction zone, southeast of Kyushu, Japan. Earth Planets Space 61:e37-e40

Nishizawa A, Kaneda K, Oikawa M (2011) Backarc basin oceanic crust and uppermost mantle seismic velocity structure of the Shikoku Basin, south of Japan. Earth Planets Space 63:151-155

Nishizawa A, Kaneda K, Oikawa M (2012) T51D-2622: compilation of seismic structural models of the Kyushu-Palau Ridge, paleo-island arc in the Philippine Sea plate, at 13-30 N. In: AGU fall meeting abstract. San Francisco. 3-7 Dec 2012

Nishizawa A, Kaneda K, Oikawa M (2013) SCG67-08: seismic structure of the Kita-Daito Basin and Minami-Daito Basin in the northwestern Philippine Sea plate. In: JpGU meeting abstract. Chiba. 19-24 May, 2013

Okino K, Kato Y (1992) What is the Oki-Daito Ridge? Rept Hydrogrp Res 28:269-292. Japanese with English abstract

Okino Y, Ohara Y, Kasuga S, Kato Y (1999) The Philippine Sea: new survey results reveal the structure and the history of the marginal basins. Geophys Res Lett 26:2287-2290

Suyehiro K, Takahashi N, Ariie Y, Yokoi Y, Hino R, Shinohara M, Kanazawa T, Hirata N, Tokuyama H, Taira A (1996) Continental crust, crustal underplating, and low-Q upper mantle beneath an oceanic island arc. Science 272:390-392

Takahashi N, Kodaira S, Klemperer S, Tatsumi Y, Kaneda Y, Suyehiro K (2007) Crustal structure and evolution of the Mariana intra-oceanic island arc. Geology 35:203-206

Tokuyama H, Kagami H, Nasu N (1986) Marine geology and subcrustal structure of the Shikoku Basin and Daito Ridges Region in the northern Philippine Sea. Bull Ocean Res Inst Univ Tokyo 22:1-169

Tokuyama H (2007) Tectonic development and reconstruction of Philippine Sea Plate since late Cretaceous. Report on Deep Sea Survey Technology for Natural Resources in Japan, JOGMEC, Tokyo, pp 430-456

Ueda Y (2004) Paleomagnetism of seamounts in the West Philippine Sea as inferred from correlation analysis of magnetic anomalies. Earth Planets Space 56:967-977

doi:10.1186/1880-5981-66-25

Cite this article as: Nishizawa et al:: Wide-angle refraction experiments in the Daito Ridges region at the northwestern end of the Philippine Sea plate. Earth, Planets and Space 2014 66:25.

\section{Submit your manuscript to a SpringerOpen ${ }^{\odot}$ journal and benefit from:}

- Convenient online submission

Rigorous peer review

- Immediate publication on acceptance

- Open access: articles freely available online

- High visibility within the field

- Retaining the copyright to your article

Submit your next manuscript at $>$ springeropen.com 